Bangladesh J. Plant Taxon. 21(1): 19-25, 2014 (June)

(C) 2014 Bangladesh Association of Plant Taxonomists

\title{
ACHENE MICROMORPHOLOGY OF SEVEN TAXA OF ACHILLEA L. (ASTERACEAE) FROM TURKEY
}

\author{
Tulay Aytas AkCin ${ }^{1}$ And Adnan AkCin ${ }^{2}$ \\ Department of Biology, Faculty of Arts and Science, Ondokuz Mayıs University, \\ Samsun,Turkey
}

Keywords: Achene micromorphology; Achillea; Slime cells; Turkey.

\begin{abstract}
Micromorphological characters of achenes in seven taxa of Turkish Achillea L. (Asteraceae) were investigated using stereomicroscope and scanning electron microscope (SEM). Some morphological descriptions of achenes were given for each species. A.biserrata Bieb. has the biggest $(0.69 \pm 0.092 \times 2.01 \pm 0.252 \mathrm{~mm})$ and A. grandiflora Friv. has the smallest $(0.30 \pm 0.018 \times 1.12 \pm 0.058 \mathrm{~mm})$ achenes. The achenes are oblonglanceolate in A.biserrata and A. teretifolia Willd. and they are oblong in the remaining taxa. In surface sculpturing, the ornamentation and slime cell distribution varied among the taxa. However, A. biebersteinii Afan. has distinct slime cells forming groups scattered over the achene surface. Mature achenes are ribbed and glabrous in all studied taxa. $A$. biserrata has distinct carpopodium structure.
\end{abstract}

\section{Introduction}

The genus Achillea L. (Asteraceae) includes about 140 species distributed in South-west Asia and South-eastern Europe (Akyalcin et al., 2011). According to recent studies, the genus Achillea is represented in Turkey by 48 species (54 taxa), 24 of which are endemic for Anatolia (Akyalcin et al., 2011). Achillea L. is classified into five sections, namely sect. Othantus (Hoffmanns. \& Link) Ehrend. \& Y. P. Guo (one species), sect. Babounya (DC.) O. Hoffm. (30 species), sect. Ptarmica (Mill.) W.D.J. Koch (2 species), sect. Anthemoideae (DC.) Heimerl (2 species) and sect. Achillea (13 species) (Huber-Morath, 1975; Duman, 2000; Arabac1 and Yıldız, 2006; Arabacı and Budak, 2009).

Achene micromorphological characters have been found useful in systematics of the family Asteraceae (Abid and Qaiser, 2007a, b; Shekhar et al., 2011). Cypselar external morphology and anatomy in members of different tribes of Asteraceae are found important for delimitation of genera (Garg and Sharma, 2007; Pandey and Kumari, 2007). Abid and Qaiser (2002) studied cypselar morphology of Dittrichia Greuter, Duhaldea DC., Inula L., Iphiona Cass. and Pentanema Cass. (Asteraceae) from Pakistan and Kashmir and concluded that two distinct groups of taxa can be recognized. It was confirmed that most of the species of Anaphalis DC. (Asteraceae) were delimited due to their distinct micromorphological characters of cypsela (Abid and Qaiser, 2007a). Zhu et al. (2006) concluded that achene wall anatomy and surface sculpturing of Lactuca L. (Asteraceae) and related genera displayed variation within genera.

Slime cells are widespread in higher plants, especially in fruits and/or seeds in different families, viz., Brassicaceae, Euphorbiaceae, Plantaginaceae, Linaceae, Malvaceae and Lamiaceae (Huang et al., 2000; Western et al., 2000). Slime cells are usually rectangular and they form ladder-like columns that are elongated in a parallel form to the long axis of the achene. Within the Asteraceae, slime cells have been reported in Achillea (Kreitschitz and Valles, 2007; Akcin and

${ }^{1}$ Corresponding author. Email: taytas@omu.edu.tr

${ }^{1}$ Department of Biology, Faculty of Arts and Science, Amasya University, Amasya 05100, Turkey 
Akcin, 2010), Anthemis L., Chrysanthemum L. (Grubert, 1974) and Artemisia L. (Huang et al., 2000; Yakovleva et al., 2002). It is also suggested that slime plays an important role in controlling of germination, mostly in plants that grow in the condition of water deficiency in arid and semiarid environments (Kreitschitz and Valles, 2007). It can also help fruit or seed dispersal and defence against pathogens (Huang and Gutterman,1999; Huang et al., 2000). Despite several studies on achene micromorphology of Achillea were carried out recently (Abid and Qaiser, 2009; Akcin and Akcin, 2010), however, there is very little information on the Turkish taxa. The main aim of the present work is to study the detailed achene morphology of some Turkish taxa belonging to the genus Achillea and to find out how useful these characters are in the systematics of the genus Achillea.

\section{Materials and Methods}

Achenes of Achillea L. taxa were studied by stereomicroscope (Leica T1A) and Scanning Electron Microscope (SEM) (JEOL-Neoscope JCM-5000). The studied plant materials were collected from different populations in Turkey. A list of specimens examined is given in Table 1. The specimens have been deposited at the Herbarium of the Department of Biology, University of Ondokuz Mayıs, Turkey (OMUB).

Table 1. List of Achillea L. taxa examined along with their vouchers.

\begin{tabular}{|c|c|}
\hline Taxon & Vouchers \\
\hline \multicolumn{2}{|l|}{ Sect. Achillea s. lat. } \\
\hline 1. Achillea biebersteinii Afan. & $\begin{array}{l}\text { A5 Amasya: Vicinity of Amasya Education Faculty, road side, } 550 \mathrm{~m} \text {, } \\
\text { 11.6.2010, T. Akcin, OMUB } 6446\end{array}$ \\
\hline 2. A. coarctata Poir. & $\begin{array}{l}\text { B5 Kayseri: Kayseri to Avanos, road side, } 1100 \text { m, 10.6. 2008, T. } \\
\text { Akcin, OMUB } 6447\end{array}$ \\
\hline 3. A. grandifolia Friv. & A6 Samsun: Kocadağ, 1200 m, 20.7.2008, A. Akcin, OMUB 6448 \\
\hline $\begin{array}{l}\text { 4. A. millefolium L. subsp. } \\
\text { millefolium }\end{array}$ & A5 Kırşehir: Mucur, 900 m, 21.6.2009, A. Akcin, OMUB 6444 \\
\hline $\begin{array}{l}\text { 5. A. millefolium } \mathrm{L} \text {. subsp. } \\
\text { pannonica (Scheele) Hayek }\end{array}$ & $\begin{array}{l}\text { A5 Amasya: Yemişen village, } 800 \mathrm{~m}, 28.7 .2010 \text {, A. Akcin, OMUB } \\
6445\end{array}$ \\
\hline \multicolumn{2}{|l|}{ Sect. Babounya (DC.) O. Hoffm. } \\
\hline 6. A. teretifolia Willd. (endemic) & $\begin{array}{l}\text { A5 Amasya: Yemişen village, road side, } 750 \mathrm{~m}, 28.7 .2010 \text {, T. Akçin, } \\
\text { OMUB } 6442\end{array}$ \\
\hline \multicolumn{2}{|l|}{ Sect. Ptarmica (Mill.) W.D.J. Koch } \\
\hline 7. A. biserrata Bieb. & A6 Samsun: Kocadağ, 1200 m, 14.7.2009, T. Akcin, OMUB 6443 \\
\hline
\end{tabular}

The achenes were examined using a stereomicroscope to ensure size, shape, colour and maturity. In order to determine the average achene sizes, 25 mature achenes were measured. For SEM observations, the mature achenes were placed on stubs using double-sided adhesive tape. Following that, they were observed and photographed with a JEOL-Neoscope JCM-5000 scanning electron microscope. The terminology of achene surface patterns adopted is mainly from Barthlott (1981, 1984), Barthlott et al. (1998) and Johnson et al. (2004). 


\section{Results and Discussion}

In the present study, achene morphology of seven taxa belonging to the genus Achillea were reported for the first time. Within the examined taxa, A. teretifolia is endemic to Turkey (Ekim et al., 2000). Achene shapes were oblong-lanceolate in A. biserrata and A. teretifolia, oblong in A. millefolium subsp. millefolium, A. millefolium subsp. pannonica, A. coarctata, A. biebersteinii and A. grandifolia (Table 2). When achene width and length were considered, different groups were obtained $(\mathrm{P}<0.001$, Table 2$)$. The widest $(0.69 \pm 0.092 \mathrm{~mm})$ and longest $(2.01 \pm 0.252 \mathrm{~mm})$ achenes were seen in A. biserrata (Table 2). Mature achenes ribbed and glabrous in all studied taxa. Achene colours vary from brown to light brown and yellowish-brown.

The position of carpopodium is almost similar (basal) in all taxa studied. However, carpopodium is with narrow circular ring in A. teretifolia (Fig. 1a), A. millefolium subsp. millefolium (Fig. 1e), A. millefolium subsp. pannonica (Fig.1h), A. coarctata (Fig. 2m), A. biebersteinii (Fig. 2j) and A. grandifolia (Fig. 20). On the other hand, A. biserrata could be separated from other taxa due to its carpopodium shape (Fig. 1c). Abid and Qaiser (2009) reported that cypselar features may also be utilized for specific delimitation as the species of
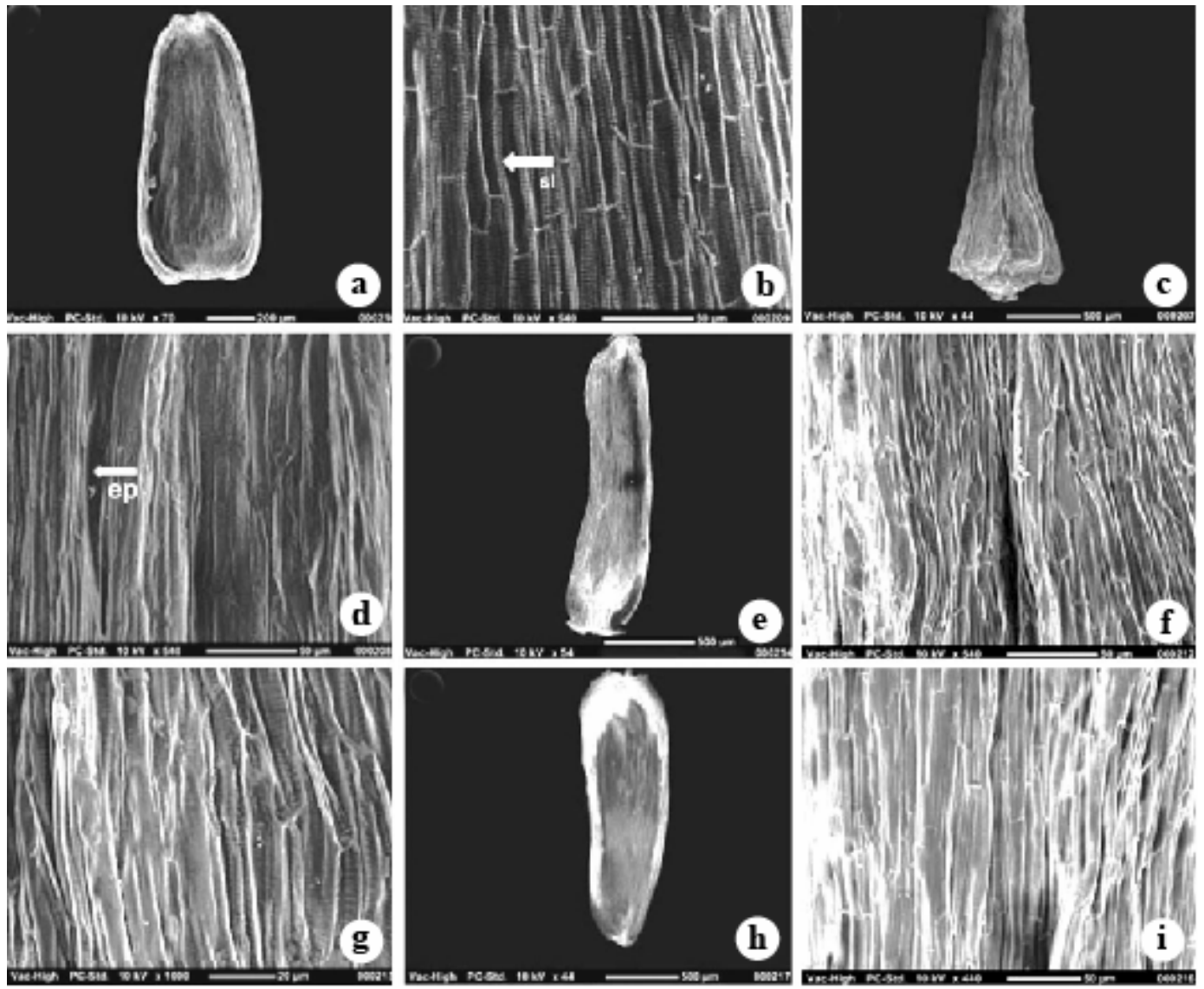

Fig. 1. SEM micrographs of achenes in Achillea L. a-b) A. teretifolia; c-d) A. biserrata; e-g) A. millefolium subsp. millefolium; h-i) A. millefolium subsp. pannonica, ep = epidermal cells; $\mathrm{sl}=$ slime cells. 


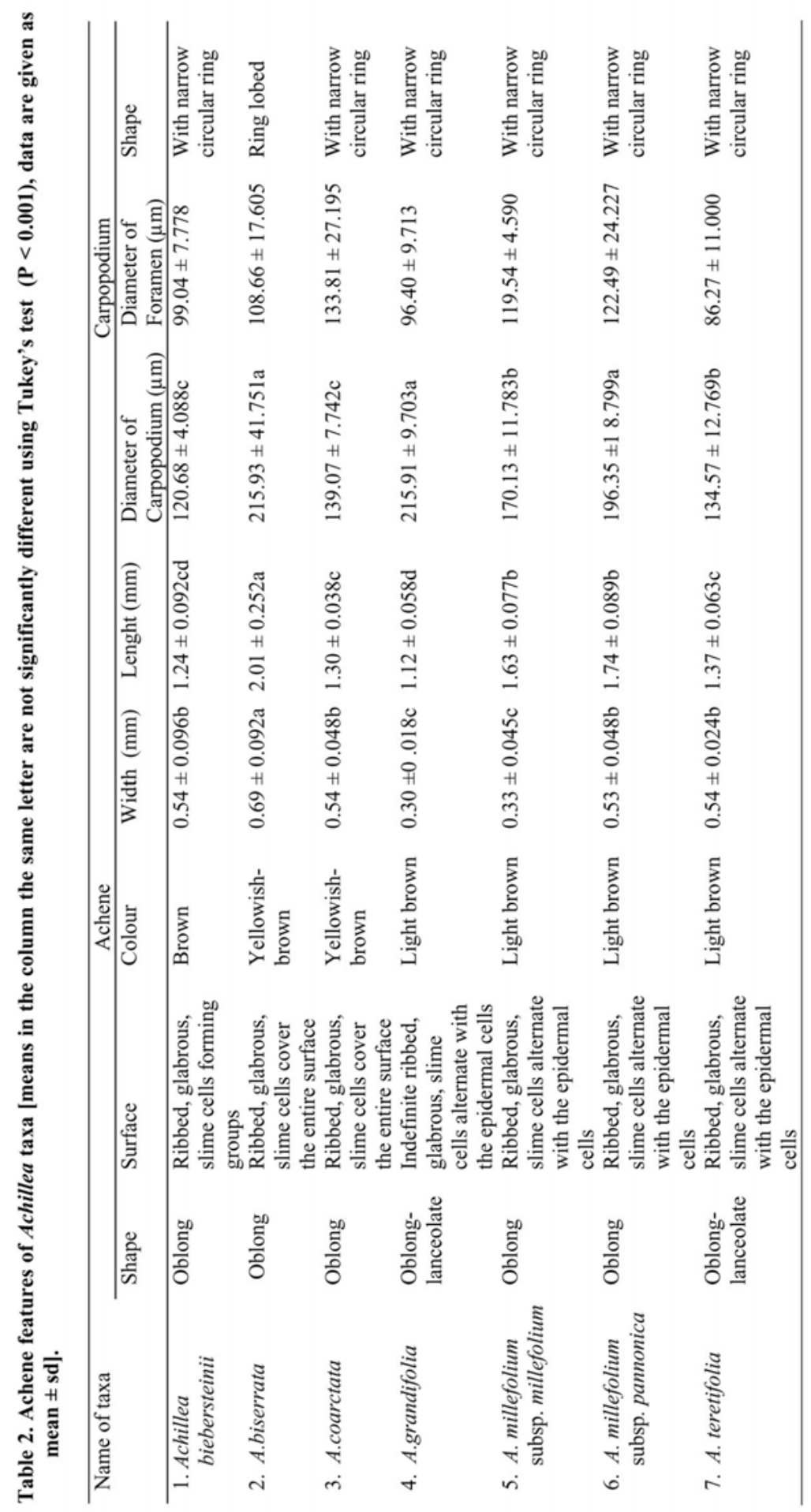


Achillea are grouped on the basis of ribbed and non-ribbed cypsela. A. millefolium was observed to have 10-12 ribbed yellowish-brown cypsela, while non-ribbed cypselas are characteristics for $A$. wilhemsii (Abid and Qaiser, 2009). Similarly, A. millefolium as indicated by Abid and Qaiser (2009) seperated from A. wilhemsii by the presence of circular ring shaped carpopodium, while A. wilhemsii has carpopodium with 4-6 lobed ring. The present investigation also support the observation of Abid and Qaiser (2009). The achenes of A. millefolium subsp. millefolium and A. millefolium subsp. pannonica have a circular ring shaped carpopodium and the ribbed surface of achenes (Figs $1 \mathrm{e}-\mathrm{i})$. However, carpopodium diameters of the achenes differ in the taxa $(\mathrm{P}<0.001$, Table 2). The widest carpopodium diameter was present in A. biserrata $(215.93 \pm 41.751 \mu \mathrm{m})$ followed by A. grandifolia $(215.91 \pm 9.703 \mu \mathrm{m})$, while it was narrow in A. biebersteinii $(120.68 \pm$ $4.088 \mu \mathrm{m})$. The diameters of foramen of carpopodium among the studied taxa were not significant $(\mathrm{P}<0.001$, Table 2).

Slime envelope formation is known in several plant families, including the Asteraceae (Kreitschitz and Valles, 2007). Within the Achillea genus, slime has been reported previously (Grubert, 1974; Akçin and Akçin, 2010). Our results confirmed the presence of slime in the investigated Achillea taxa. Slime cells are usually rectangular and they form ladder-like columns that are elongated in a parallel form to the long axis of the achene (Figs. 1b, 2k,1,n). Slime cells can either cover almost entire surface of the achene as in A. biserrata (Fig. 1d) and A. coarctata (Fig. 2n), or alternate with the epidermal cells in A. millefolium subsp. millefolium (Figs 1f-g), and A. biebersteinii (Figs 2k-1). A distinct pattern occurs in A. biebersteinii achenes (Figs 2k-1), where slime cells form groups scattered over the achene surface. Slime formation on the fruit and/or seed surface is known to be an ecological adaptation to limited availability of water (Huang and Gutterman, 1999; Huang et al., 2000). Several authors showed that the presence of the slime envelope facilitates the adherence of achenes to the soil surface and makes germination easier (Huang et al., 2000; Kreitschitz and Valles, 2007).

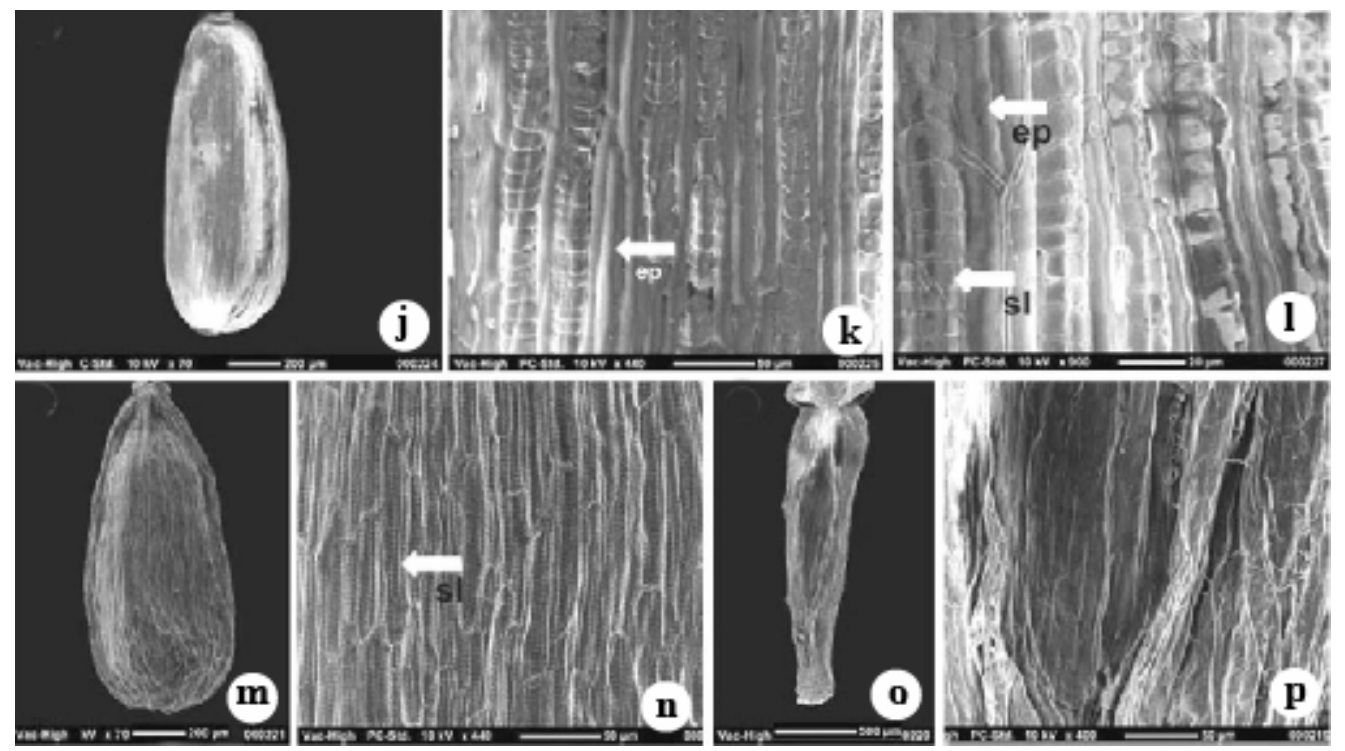

Fig. 2. SEM micrographs of achenes in Achillea L. j-1) A. biebersteinii; m-n) A.coarctata, o-p) A. grandifolia, ep = epidermal cells; $\mathrm{sl}=$ slime cells. 
Taxa such as A. millefolium subsp. millefolium, A. millefolium subsp. pannonica, A. teretifolia, A. coarctata, A. biebersteinii occurring in less fertile and often arid location (HuberMorath, 1975) are characterized by the presence of numerous strands of slime cells. Slime formation also plays an important role in the control of germination, mostly in plants that grow in the condition of water deficiency in arid and semiarid environments, thus faciliating imbibing and maintenance of the water (Kreitschitz and Valles, 2007).

It was also reported that slime cells in species growing in wet environment such as stream sides and meadows may not mature or function properly (İnceer et al., 2012). However, in A. biserrata and A. grandifolia, often growing around wet environment such as coniferous forest (Huber-Morath, 1975), the presence of a slime envelope may play an important role in dispersal of this species. Huang et al. (2000) reported that the slime can reduce the specific weight of diaspores thus facilitating their transportation with water current (hydrochory). In the present study, there are differences in distribution of the slime cells in the examined taxa. Slime cells in A. teretifolia similar to A. coarctata are usually ladder-like coloumns elongated parallelly to long axis of the achene (Figs 1b, 2n). However, A. biebersteinii has a distinct slime cells forming groups scattered over the achene surface (Figs 2k-1). For this reason, these species could be further seperated by the sculpture of achene surface. A. grandifolia is separated from the remaining species by having indefinite individual ribs (Fig. 2p). It was also determined that slime cells alternate with epidermal cells in A. millefolium (Figs 1f,g,i), while it covers almost the entire surface of achene in A. biserrata (Fig. 1d) and A. coarctata (Fig. 2n). These results confirmed that slime cells on the fruit surface is associated with ecological adaptation. Akçin and Akçin (2010) reported that achenes of A. phrygia have myxogenic cells (slime-producing) almost throughout the entire surface but slime cells are more restricted in A. gypsicola. Such a relationship was reported for Lamiaceae (Mosquero et al., 2004), Artemisia (Asteraceae) (Kreitschitz and Valles, 2007) and Tripleurospermum (İnceer et al., 2012).

We can conclude that this work helps to charracterize the taxa of Achillea L. Studies employing additional taxa of the genus are necessary which might further contribute to utilization of achene micromorphological characters as significant attributes in classification of the species.

\section{Acknowledgements}

We would like to thank the staff of Faculty of Science and Literature Directorship of Basic Sciences Research and Applied Center of Balıkesir University (BUTAM) for taking microphotographs of achenes.

\section{References}

Abid, R.D. and Qaiser, M. 2002. Cypsela morphology of Inula L. (s. str.) and its allied genera (Inuleae: Compositae) from Pakistan and Kashmir. Pak. J. Bot. 34(3): 207-223.

Abid, R.D. and Qaiser, M. 2007a. Micromorphology of cypsela in the tribe Plucheeae from Pakistan. Pak. J. Bot. 39(3): 671-677.

Abid, R.D. and Qaiser, M. 2007b. Cypsela morphology of the genus Anaphalis DC. (GnaphalieaeAsteraceae) from Pakistan. Pak. J. Bot. 39(6): 1897-1906.

Abid, R.D and Qaiser, M. 2009. Taxonomic significance of the cypsela morphology in the tribe Anthemideae (Asteraceae) from Pakistan and Kashmir. Pak. J. Bot. 41(2): 555-579.

Akcin, T.A and Akcin, A. 2010. Morphological and anatomical characteristics and taxonomical significance of achene micromorphology of Achillea phrygia and A. gypsicola (Asteraceae), endemic to Turkey. Nordic J. Bot. 28(1): 65-73. 
Akyalcın, H., Arabacı, T. and Yıldız, B. 2011. Pollen morphology of six Achillea L. sect. Achillea (Asteraceae) species in Turkey. Turkish J. Bot. 35: 183-201.

Arabac1, T. and Budak, Ü. 2009. Achillea hamzaoglui (Asteraceae), a new species from Turkey. Annales Botanici Fennici 46: 459-463.

Arabacı, T. and Yıldız, B. 2006. Rediscovery of Achillea boissieri Hausskn. ex Boiss. later 140 years. Feddes Repertorium 117: 459-463.

Barthlott, W. 1981. Epidermal and seed surface characters of plants: Systematic applicability and some evolutionary aspects. Nordic J. Bot. 1(3): 345-355.

Barthlott, W. 1984. Microstructural features of seed surfaces. In: Heywood, V.H. and Moore, D.M. (Eds), Current Concepts in Plant Taxonomy, Academic Press, London, pp. 95-105.

Barthlott, W., Neinhuis, C., Cutler, D., Ditsch, F., Meusel, I., Theisen, I. and Wilhelmi, H. 1998. Classification and terminology of plant epicuticular waxes. Bot. J. Linn. Soc. 126(3): 237-260.

Duman, H. 2000. Achillea L. In: Güner, A., Özhatay, N., Ekim, T. and Başer, K.H.C. (Eds), Flora of Turkey and the East Aegean Islands (Suppl. 2), Vol. 11, Edinburgh University Press, Edinburgh, pp. 158-159.

Ekim, T., Koyuncu, M., Vural, M., Duman, H., Aytaç, Z. and Adıgüzel, N. 2000. Red Data Book of Turkish Plants, Ankara, No. 18, pp. 1-245.

Garg, S.K. and Sharma, K.C. 2007. Taxonomical significance of the micromorphological and scanning electron microscopic surface patterns of cypselas in some members of the tribe Heliantheae (Asteraceae). Feddes Repertorium 118: 165-191.

Grubert, M. 1974. Studies on the distribution of myxospermy among seeds and fruits of Angiospermae and its ecological importance. Acta Biologica Venezuelica 8: 315-551.

Huang, Z. and Gutterman, Y. 1999. Water absorption by mucilaginous achenes of Artemisia monosperma: floating and germination as affected by salt concentrations. Israel J. Plant Sci. 47: 27-34.

Huang, Z., Gutterman, Y. and Hu, Z. 2000. Structure and function of mucilaginous achenes of Artemisia monosperma inhabiting the Negev desert of Israel. Israel J. Plant Sci. 48(4): 255-266.

Huber-Morath, A. 1975. Achillea L. In: Davis, P.H. (Ed.), Flora of Turkey and the East Aegean Islands, Vol. 5. Edinburgh University Press, pp. 224-252.

İnceer, H., Bal, M., Ceter, T. and Pinar, N.M. 2012. Fruit structure of 12 Turkish endemic Tripleurospermum Sch. Bip. (Asteraceae) taxa and its taxonomic implications. Plant Syst. Evol. 298: 845-855.

Johnson, L.A., Huish, K.H. and Portert, J.M. 2004. Seed surface sculpturing and systematic significance in Gilia (Polemoniaceae) and segregate genera. International J. Plant Sci. 165(1): 153-172.

Kreitschitz, A. and Valles, J. 2007. Achene morphology and slime structure in some taxa of Artemisia L. and Neopallasia L. (Asteraceae). Flora 202(7): 570-580.

Mosquero, M.A., Juan, R. and Pastor, J. 2004. Observaciones micromorfologicas y anatomicas en nuculas de Prunella L. y Cleonia L. (Lamiaceae) del suroeste de Espana. Acta Botanica Malacitana 29: 203-214.

Pandey, A.K. and Kumari, A. 2007. Anatomical patterns of pericarp in Asteraceae. In: Chauhan, S.V.S., Rana, A. and Chauhan, S. (Eds), Plant Reproductive Biology and Biotechnology. Aavishkar Publisher, Jaipur, pp. 64-77.

Shekhar, S., Pandey, A.K. and Anderbergh, A.A. 2011. Cypsela morphology and anatomy in some genera formerly placed in Inula (Asteraceae: Inuleae-Inulinae). Rheedea 21(1): 13-22.

Western, T.L., Debra, J.S. and Haughn, G.W. 2000. Differentation of mucilage secretory cells of the Arabidopsis seed coat. Plant Physiol. 122(2): 345-355.

Yakovleva, O.V., Korobkov, A.A. and Boyko, E.V. 2002. Structure of mucilage containing cells in achene pericarp of some species of Artemisia (Asteraceae). Botanicheskii Zhurnal 87: 1-14.

Zhu, S.X., Qin, H.N. and Shih, C. 2006. Achene wall anatomy and surface sculpturing of Lactuca L. and related genera (Compositae: Lactuceae) with notes on their systematic significance. J. Integr. Plant Biol. 48(4): 390-399. 